\title{
Sobre a correspondência de Espinosa com Tschirnhaus
}

Marilena Chaui*

Resumo: A correspondência de Espinosa com Tschirnhaus, iniciada pouco antes da publicação do Tratado teológico-político e terminada alguns meses antes da morte do filósofo, é de marcada importância não só por conter os últimos escritos de Espinosa, mas sobretudo porque nela alguns dos temas mais importantes de sua filosofia são discutidos - nas primeiras, a relação entre necessidade e liberdade; nas seguintes, a distinção entre idéia verdadeira e adequada; nas últimas, o infinito atual, a possibilidade da exposição geométrica da metafísica e de uma física a priori. Neste ensaio, mencionaremos a presença implícita de Leibniz nas últimas cartas de Tschirnhaus, mas trataremos apenas da primeira troca de cartas, cujo assunto é a divergência entre Tschirnhaus e Espinosa no tocante à liberdade.

Palavras-chave: liberdade - necessidade - fatalismo - livre-arbítrio - vontade - contingência

Muita vez, o leitor da Correspondência de Espinosa se sente impelido pelo desejo de escrever sobre ela como Umberto Eco escreveu $O$ nome da rosa, uma história de detetive, à cata de indícios para descobrir um texto perdido.

* Professora titular do Departamento de Filosofia da Faculdade de Filosofia, Letras e Ciências Humanas da Universidade de São Paulo - FFLCH-USP, e presidente da Associação de Estudos Filosóficos do Século XVII. 
Como se sabe, das 50 cartas de Espinosa conhecidas até hoje, apenas 13 são autógrafas. Além disso, os estudos críticos recentes, iniciados nos anos 1970 por F. Akkerman e F. Mignini e prosseguidos por grupos de trabalho, em diferentes países, como o Groupe de Recherches Spinozistes, dirigido por Pierre-François Moreau, assim como tradutores isolados, como E. Curley e A. Domínguez, indicam que a edição Gebhardt da obra e, portanto, da Correspondência de Espinosa deixa a desejar ${ }^{(1)}$. A esse problema grave, é preciso acrescentar dois outros, com os quais se complica bastante a situação das Cartas: em primeiro lugar, os critérios usados pelos amigos para a publicação da correspondência nos Opera Posthuma (Akkerman 4; Akkerman \& Hubbeling 5); em segundo, a queima de papéis que, de acordo com alguns biógrafos (Meinsma 14), Espinosa teria feito na véspera de sua morte.

No que tange ao primeiro problema, ao que tudo indica, os amigos decidiram publicar somente cartas que pudessem cumprir a dupla função de uma carta seiscentista, isto é, ter a forma de um pequeno tratado sobre uma ou algumas questões controvertidas, destinado a circular entre os estudiosos, e indicar o largo espectro de questões e interlocutores do filósofo, sob a forma de objeções e respostas. Por esse critério, torna-se compreensível o pequeno número de cartas dos ou para os amigos, a ausência de cartas de caráter estritamente pessoal e a publicação apenas de cartas de amigos nas quais estão postas questões filosófico-científicas e filosófico-políticas. Um segundo critério parece ter sido seguido pelos editores, que excluíram cartas de pessoas que não poderiam ou não desejaram ter seus nomes numa obra de Espinosa, bem como trechos de cartas em que tais nomes poderiam estar mencionados com alguma indicação precisa de que Espinosa tivera alguma relação ou algum trato com tais pessoas. Isso explicaria o fato de que saibamos, por outras publicações de correspondências do período, que houve gente que escreveu a Espinosa e dele recebeu resposta, mas tais cartas não constam entre as publicadas nas Obras póstumas. Isso também explicaria por que temos respostas de Espinosa a cartas não publicadas (como as do matemático cartesiano Hudde) ou por que algumas cartas se reduzem 
a um parágrafo (como a Carta 66 de Espinosa a Tschirnhaus e a Carta 80 de Tschirnhaus a Espinosa).

Não sabemos, porém, se houve outros critérios de edição, pois, às vezes, Espinosa faz menção a cartas suas ou de outros, as quais, no entanto, não foram publicadas (como se infere da afirmação de Espinosa, na Carta 58 , de que teria enviado - missi - a Rieuwertz exemplos de controvérsia verbal entre pessoas com o mesmo pensamento ou de pensamento diverso). Por não sabermos dos critérios exatos da edição, não temos como saber se houve correspondência com pessoas que são mencionadas em cartas de ou para Espinosa (como, por exemplo, a referência a Serrarius, no início da correspondência com Oldenburg) e, em caso afirmativo, o que sucedeu às cartas.

À luz dessas suposições sobre os possíveis critérios que presidiram a publicação da Correspondência, podemos indagar: o que fizeram os amigos com as cartas não publicadas? Ao que parece, não as suprimiram, pois novas cartas têm sido encontradas, desde o século XIX, e nada nos impede de esperar que outras venham à luz ${ }^{(2)}$. Podemos ainda indagar: o que fizeram com os trechos de cartas suprimidos da publicação? A resposta talvez seja a mesma que no caso anterior e, quiçá, podemos esperar, um dia, encontrar as cartas integrais. Isso seria iluminador para muitos aspectos da Correspondência e um exemplo tirado da troca epistolar com Tschirnhaus pode, aqui, servir de ilustração.

Na Carta 70, de agosto de 1675 , Schuller, escrevendo ainda uma vez em nome de Tschirnhaus, conta que, em Paris, este acaba de conhecer Leibniz, de quem teve boa impressão, dele ouvindo palavras de estima sobre o Tratado teológico-político, e indaga se lhe pode transmitir o manuscrito da Ética. Espinosa responde com cautela: conhece Leibniz (não menciona visitas que este lhe fez, mas uma carta que lhe deu a impressão de uma pessoa de espírito livre e muito versada em ciências), porém deseja, primeiro, saber o que um conselheiro de Frankfurt veio fazer na França ${ }^{(3)}$ e julga necessário que Tschirnhaus o conheça melhor, avalie seu caráter e só então, se for o caso, lhe transmita o manuscrito. Ora, a carta seguinte, de maio de 1676, agora do punho de Tschirnhaus, começa abruptamente e, na versão 
latina das Obras póstumas, se reduz a um parágrafo, enquanto na versão holandesa possui um parágrafo final em que Tschirnhaus comunica a Espinosa que Leibniz o avisou de que o preceptor do Delfim, o padre Huet, se prepara para publicar um livro contra o TTP. Tendo em vista as reservas de Espinosa sobre a entrega do manuscrito da Ética a Leibniz e a sugestão de que Tschirnhaus o conheça melhor, é de se supor que este não reduzisse as informações sobre Leibniz a esse pequeno parágrafo, que sequer consta da obra latina. Certamente algo mais foi dito na carta de Tschirnhaus, pois, no início de 1676, Leibniz vai à Holanda, para encontrar-se com Huygens e Leuwenhoeck, passa por Amsterdã, onde se encontra com os amigos mais próximos de Espinosa, isto é, Meijer, Bouwmeester e Jelles e, em cartas a Galloys, no início $1677^{(4)}$, escreve que esteve com Espinosa várias vezes e com ele discutiu longamente.

A crermos em Leibniz, nessas conversas, teria explicado a um surpreendido Espinosa, a falsidade das leis do movimento propostas por Descartes. Teria também lhe apresentado uma prova a priori da existência de Deus, fundada na idéia da copossibilidade das perfeições infinitas num ser infinito que, sendo logicamente possível, seria metafisicamente necessário. Segundo Leibniz, Espinosa teria visto e aprovado sua argumentação e, num gesto de gentileza, ter-lhe-ia lido sua própria demonstração da existência de Deus, isto é, a Proposição 11 da Parte I da Ética - assim, enquanto um deles provava a existência de Deus pela passagem do possível ao necessário e pela afirmação do princípio de razão suficiente, o outro provava essa existência pela idéia de ser absolutamente infinito e a fundamentava no princípio de razão.

No entanto, por algum motivo que até o momento desconhecemos, nem Espinosa nem Tschirnhaus jamais deram a Leibniz o manuscrito da Ética, o que, entretanto, parece não haver impedido que este possuísse os enunciados das definições e proposições da Parte I, copiados e enviados por Schuller ${ }^{(5)}$, a quem recorreu para a obtenção do texto completo, sobretudo ao ter notícia, por este último, de que Espinosa estava à beira da morte. Schuller escreve a Leibniz, prometendo-lhe o manuscrito, que, todavia, não encontrou, ainda que, segundo suas próprias palavras, tivesse "revolvido todos os papéis do senhor Espinosa, antes e depois de sua morte"(6). 
Quanto ao nosso segundo problema, a queima de papéis pelo próprio Espinosa, pode-se supor que tenha queimado cartas pessoais (ele prometera, por exemplo, a Bouwmeester jamais divulgar a correspondência que tivessem) e escritos que não julgava em condições de publicação, o que, por outro lado, indica que o inacabamento do De Emendatione e do Politicus não os impediria de vir a público, uma vez que não os queimou.

Essas observações preliminares visam apenas recordar alguns problemas postos pela Correspondência de Espinosa e preparar algumas considerações breves que faremos acerca das últimas cartas de Tschirnhaus ${ }^{(7)}$.

\section{II}

Médico e matemático, pertencente à pequena nobreza alemã, Tschirnhaus, hoje mais conhecido por sua correspondência com Espinosa do que por sua própria obra, foi, entretanto, celebrado em sua época e seus trabalhos eram lidos e citados nas universidades alemãs até o século XVIII. Entre seus feitos científicos, ligados aos estudos das curvas e tangentes, registra-se a descoberta da chamada "cúbica de Tschirnhaus" e da "cáustica de reflexão", que se forma quando se aproxima uma chama de um espelho cilíndrico, estudo que, juntamente com a obra de Desargues, levará Leibniz a redefinir a tangente, considerando-a não mais uma reta e sim uma curva envolvida por outra.

Se considerarmos que houve, pelo menos, três círculos de amigos de Espinosa: o do período de Amsterdã/Rijnsburg, com amigos como Koerbagh, Boreel, Balling, de Vries, sucedido pelo de Haia/Voorburg, com a presença de amigos como Meijer, Bouwmeester e Jelles, e um terceiro, posterior à morte desses últimos e à morte de Espinosa, pode-se considerar esse terceiro círculo como o de Tschirnhaus, como atesta a correspondência deste com seus amigos holandeses (círculo que, em estudos recentes, tem sido caracterizado como de amigos interessados em filosofia natural, matemáti- 
ca e na adaptação da Ética ao ideal antigo do sábio imperturbável). Estudando medicina em Leiden e residindo na mesma pensão que Schuller, seu compatriota e também estudante de medicina, ambos travaram conhecimento com Espinosa, o que não surpreende, uma vez que, segundo a historiografia mais recente, o filósofo manteve contatos com membros do corpo docente e discente da Universidade de Leiden.

Foi inegável a estima de Tschirnhaus por Espinosa, a melhor prova disso estando no fato de que este lhe deu uma cópia dos manuscritos do $D e$ Emendatione e da Ética, o que só fizera para os amigos estimados e muito próximos. Essa estima era recíproca: uma carta de Schuller, de 1675 (Carta 63), relata que, estando em Londres, Tschirnhaus defendeu as idéias de Espinosa das objeções de Boyle e de Oldenburg e foi responsável pela nova leitura do TTP por Oldenburg e pela mudança de posição deste último com relação à obra. Também uma carta de Schuller, de 1675 (Carta 70), relata que, por recomendação de Espinosa, tendo travado conhecimento com Huygens, este, depois de exprimir sua alta consideração pelo filósofo, indagou se Tschirnhaus conhecia alguma nova obra, além do TTP, que lhe disse que, a não ser os Princípios da filosofia cartesiana, nada sabia. E Schuller comenta: "Ele espera que isso vos agrade", pois a promessa de sigilo sobre a Ética nunca foi quebrada pelo amigo. Tanto assim, que é, nessa mesma carta, que Schuller se refere aos primeiros contatos de Tschirnhaus com Leibniz em Paris e transmite a indagação do amigo se haveria consentimento de Espinosa para transmitir o manuscrito da Ética ao "conselheiro de Frankfurt". A negativa de Espinosa foi respeitada por Tschirnhaus, ainda que soubesse que, de alguma maneira, Leibniz havia conseguido o manuscrito da Parte I.

Embora, como escreve um intérprete da obra de Tschirnhaus, este possa ser considerado um "espinosista herético" (Wurtz 20) e embora uma carta de Pieter van Gent, seu amigo e de Espinosa, pertencente ao terceiro círculo de espinosanos holandeses, julgue inadmissível que Tschirnhaus mantenha a crença na imortalidade da alma (Vermij 19), a proximidade entre Tschirnhaus e Espinosa se mostra não só nas cartas trocadas entre ambos e na confiança recíproca que marcou suas relações, mas também na cor- 
respondência de Tschirnhaus com Leibniz (em que a admiração e o respeito por Espinosa são mantidos e defendidos) e sobretudo na obra filosófica de Tschirnhaus, a Medicina mentis, cuja estrutura se aparenta à do De Emendatione, como se Tschirnhaus tivesse procurado concluir o que ficara inacabado em Espinosa, não apenas no tocante ao método, mas também no tocante à física e à relação entre razão e experiência. Dessa proximidade e dessa intenção dá provas o Prefácio da Medicina mentis.

Tschirnhaus inicia o Prefácio afirmando que nada produz uma alegria tão intensa nem uma fruição tão completa quanto o conhecimento verdadeiro. Se nisso está a posse de um "espírito verdadeiramente feliz", é preciso deduzi-lo de um dom divino feito aos homens, o entendimento, "pois é por seu intermédio que é permitido ao homem contemplar mentalmente verdades profundas e alcançar o contentamento d'alma" (Tschirnhaus 18, p. 38). Assim sendo,

"[...] tenho a intenção de apresentar neste livro um método para perfazer da melhor maneira nosso entendimento, na medida em que isso é possível por meios naturais. Nenhuma reflexão, na verdade, será mais útil, no limiar dessa empreitada do que examinar cuidadosamente a que grau preciso de perfeição o entendimento pode ser levado, a fim de que qualquer homem desejoso de adquirir a sabedoria tenha sempre diante dos olhos o objetivo rumo ao qual deve dirigi-lo" (id., ibid.).

Para tanto, continua Tschirnhaus, é preciso libertar-se dos preconceitos e das fantasias que reduziram a filosofia ao "filósofo do verbo", ocupado com as denominações das coisas, e passar à filosofia praticada pelo "filósofo do real", título que cabe

"[...] somente àquele que acedeu a um nível de conhecimento tal que constata, fazendo em si mesmo a experiência, que está em seu poder colocar às claras, pelas forças próprias de seu espírito, tudo o que é acessível ao entendimento humano [...] e essa ciência, ou me- 
lhor, essa arte de descobrir é precisamente a filosofia autêntica [...]. Por isso decidi expor ao leitor tão claramente quanto possível, neste livro, esse método, isto é, uma filosofia conforme à idéia que acabei de esboçar [...]. Preferi intitulá-lo Medicina do espírito e do corpo a fim de tornar a filosofia atraente para todos. E a filosofia autêntica tem exatamente a tarefa de mostrar com clareza o quanto a saúde do corpo e do espírito fazem falta a todos os homens, assim como deve mostrar com clareza a quais remédios, apropriados aos males, convém recorrer" (Tschirnhaus 18, p. 40-1).

O projeto de Tschirnhaus era o de dividir a obra em duas partes principais: a primeira, dedicada aos "preceitos gerais da arte de descobrir" e na qual a medicina do espírito e do corpo incidiria diretamente não só na metafísica, mas também na moral; a segunda, constituída de tratados independentes, estaria voltada para os "preceitos especiais da arte de descobrir", isto é, dedicados à matemática, aos experimentos e à física. Esse projeto lança muita luz sobre as cartas trocadas com Espinosa, sobre o conjunto de questões postas por ele ao filósofo sobre a força do intelecto para tirar apenas de si o conhecimento verdadeiro, sobre a relação entre razão e experiência, e sua insistência para que Espinosa publique o método e a física.

A correspondência com Tschirnhaus, excetuada a mantida com Oldenburg, é a mais longa (pelo menos no estado atual da Correspondência): são 11 cartas, escritas entre 1674 e 1676 . É também a mais importante, não só porque as de 1676 constituem o conjunto dos últimos escritos de Espinosa, mas também, se considerarmos o seu todo, porque nelas são tratadas as questões mais candentes da obra espinosana: a recusa do livre-arbítrio, a explicação da distinção entre idéia adequada e idéia verdadeira, as conseqüências da definição da mente como idéia do corpo e de ambos como modos de atributos divinos, a nomeação dos modos infinitos imediatos e mediato, a gênese necessária de todas as coisas a partir da necessidade da essência de Deus, a produção dos corpos e a dedução a priori dessa produção a partir do atributo extensão, a idéia de infinito atual em matemática. 
Uma leitura atenta desse conjunto de cartas mostra que variam não só quanto aos assuntos, mas também pelo tom, e por isso propomos escandi-lo em três etapas: a primeira é a das cartas de 1674, sobre o livre-arbítrio; a segunda, a das cartas de 1675 , sobre o método e a física; e a terceira inclui as duas últimas cartas de 1675 e as quatro de 1676, referindo-se agora prioritariamente à ontologia. Na primeira etapa, isto é, quando os dois correspondentes ainda não se conhecem muito bem, Tschirnhaus, que possivelmente teria lido, até então, os Princípios da filosofia cartesiana e os Pensamentos metafísicos, se apresenta como um cartesiano que faz objeções a um outro cartesiano; na segunda, depois que os laços de amizade se estreitaram e que Tschirnhaus leu o manuscrito do Tratado da emenda do intelecto e, pelo menos, a Parte I da Ética, o tom de suas cartas é um misto de consulente e aprendiz; na terceira, o de um pensador que apresenta objeções a um outro em quem confia e cujas idéias pretende adotar. Nossa primeira impressão é de acompanharmos a formação filosófica de um jovem talentoso, movido pelo desejo sincero de conhecimento, que começa cartesiano e pretende terminar espinosano, sem abandonar restrições e objeções que julga pertinentes.

Todavia, há algo na mudança de tom das últimas cartas de Tschirnhaus que nos leva a uma outra conjetura. $\mathrm{O}$ que teria levado à mudança? Podemos oferecer duas suposições. Podemos começar supondo que é possível que, na altura de 1675-6, Tschirnhaus já estivesse projetando escrever sua obra sobre a matemática e a física e, por pretender que fossem fiéis ao pensamento de Espinosa, exige que este seja mais claro e mais explícito. Podemos, porém, conjeturar algo bastante diverso. De fato, as duas últimas cartas de Tschirnhaus são quase as de um opositor que cobra demonstrações, critica obscuridades, confronta Espinosa com Descartes, e isso nos leva a conjeturar que essa mudança se deve ao fato de que as últimas cartas de Tschirnhaus são, na verdade, a apresentação de questões postas por Leibniz a Espinosa. E que Espinosa sabe disso. Mais ainda. É provável que, na altura de sua primeira carta parisiense, ao pedir permissão para comunicar o manuscrito da Ética, Tschirnhaus não soubesse que, desde 1671, Leibniz aprovara a crítica ao TTP, feita por Graevius, professor da Univer- 
sidade de Utrecht que, pelos menos até 1673 , fora um próximo de Espino$\mathrm{sa}^{(8)}$ e sobre quem Meinsma observa que "pode ter sido muito competente, mas no plano da amizade foi sem caráter" ${ }^{(9)}$. Espinosa, porém, sabia do tratamento que a obra vinha recebendo não só na Holanda, mas também na Inglaterra, na França e na Alemanha, e, muito possivelmente, sua cautela inicial não decorreu apenas da questão política ("o que faz na França um conselheiro de Frankfurt?”), mas também de ter alguma notícia das relações de Leibniz com o mundo bem-pensante holandês. O tom de suas respostas às últimas cartas de Tschirnhaus, se for válida nossa conjetura de que o interlocutor implícito é Leibniz, pode indicar que não vê neste último um amigo e um aliado.

Assim, o conjunto dessas cartas possui um aspecto curioso: as primeiras respostas de Espinosa a Tschirnhaus foram endereçadas a Schuller e as últimas respostas, endereçadas a Tschirnhaus, foram dirigidas a Leibniz!

Tendo em vista os cortes nos textos de várias cartas, feitos pelos amigos editores das Obras póstumas, não podemos saber se Tschirnhaus apresentou as objeções como vindas de Leibniz ou como suas, mas nascidas de suas conversas com Leibniz; nem podemos saber se, ao responder, Espinosa lhe disse para comunicar a Leibniz as respostas ou se, pelo tom pouco caloroso e pela brevidade, deu a entender a quem respondia de fato. Nessas circunstâncias, só podemos conjeturar a partir de alguns indícios de que as questões são de Leibniz e de que as respostas são enviadas a Leibniz, por intermédio de Tschirnhaus.

Do lado de Tschirnhaus, os principais indícios para nossa conjetura são: em primeiro lugar, a mudança de tom, já observada acima; em segundo, o aparecimento de uma questão sobre a Carta 12 (ou a Carta sobre o infinito), que Tschirnhaus possuía de longa data e que não lhe despertara questões até então, mas essa carta é uma aquisição recente de Leibniz, que, portanto, acaba de lê-la no momento em que se dedica justamente às questões do cálculo infinitesimal, e, pela seqüência da correspondência posterior de Tschirnhaus com ele acerca do cálculo, das questões metodológicas envolvidas e, nessas cartas, da crítica leibniziana ao De emendatione, podemos supor ou que Tschirnhaus deseja estar mais seguro para argumentar 
com Leibniz ou que está expondo objeções leibnizianas. Em terceiro, a maneira como é recolocada uma questão que aparecera em carta anterior, sobre a possibilidade de uma dedução a priori dos corpos a partir da extensão infinita. De fato, se lermos as últimas indagações de Tschirnhaus juntamente com os comentários, feitos posteriormente por Leibniz sobre as proposições 16,17 e 28 da Parte I da Ética ${ }^{(10)}$, podemos supor que, embora não passando a Leibniz o manuscrito da Ética, Tschirnhaus sabe que Leibniz possui o manuscrito da Parte I e pode ter discutido com ele suas próprias dificuldades com a Proposição I, P16, suscitando em Leibniz indagações ou sendo suscitado por Leibniz a propor as perguntas que enviaria a Espinosa. Além disso, é óbvio que Tschirnhaus expôs a Leibniz o que julgara ser a estrutura geral da Ética, pois é graças a ele (que declara que a obra espinosana será sobre Deus, a mente e a beatitude, uma medicina mentis e uma medicina corporis) que Leibniz fará a célebre afirmação de que o filósofo vulgar começa a creaturis, Descartes começa $a$ mente, enquanto Espinosa começa $a$ Deo. Em quarto lugar, a ausência de resposta de Tschirnhaus a essa que será, pelo menos até o momento, a última carta de Espinosa, o qual pede notícias sobre a refutação do TTP por Huet, informação que Leibniz, freqüentador da corte de Luís XIV, certamente havia de possuir, mesmo porque fora ele quem avisara Tschirnhaus da obra do preceptor do Delfim. Além disso, Tschirnhaus sabe, por Schuller, se não por outros amigos, que Espinosa está bastante doente e é estranho que não lhe tivesse escrito, o que seria o caso se a Carta 83 lhe tivesse sido diretamente dirigida.

E, por fim, possuímos a correspondência mantida por Leibniz com Tschirnhaus após a morte de Espinosa. Em suas cartas, Leibniz insiste numa nova teoria da definição cujo rigor e exatidão serão máximos com a introdução da característica universal e explica ao seu correspondente as limitações das noções de idéia verdadeira e de definição perfeita do De emendatione. A aceitação como axioma ou verdade universal de que "tudo o que pode ser tirado da definição pode ser enunciado da coisa definida", afirma Leibniz, só será aceitável se uma definição real empregar noções possíveis e compatíveis de tal maneira que possa ser transformada num teorema demonstrável. Ao mesmo tempo, Leibniz insiste em que Tschirnhaus se dê 
conta de que Espinosa erra com Descartes, pois, por defeito da definição, teria considerado o entendimento e a extensão noções primitivas de que tudo poderia ser deduzido (a variedade das idéias e dos corpos), além de se enganar por manter a extensão no seu sentido puramente cartesiano de extensão geométrica. Assim, o leitor da correspondência de Tschirnhaus com Espinosa entende, finalmente, a origem e o sentido das últimas cartas trocadas entre eles, pois é evidente que Tschirnhaus exprime inquietações que só lhe poderiam vir das considerações leibnizianas, ou, como supomos aqui, está simplesmente enviando a Espinosa objeções de Leibniz.

De fato, se examinarmos as últimas cartas de Tschirnhaus a Espinosa, veremos sobretudo sua insistência para que Espinosa explique como pode deduzir da definição geométrica da extensão a multiplicidade e variedade dos corpos. Mas não só isso. O Prefácio da Medicina mentis, de que mencionamos algumas passagens, abre-se com uma idéia de Deus que é uma tentativa para reunir a idéia espinosana de potência absolutamente infinita e a idéia leibniziana de sabedoria e bondade infinitas ou da copossibilidade das perfeições divinas:

"Se, de um ponto de vista filosófico, considera-se antes de tudo a potência infinita de Deus, que produziu criaturas inumeráveis e, ao mesmo tempo, muito diferentes, em um universo tão vasto, e também sua inefável sabedoria, sob a influência da qual essa potência se exerce com uma engenhosidade tal, que toda coisa se produz segundo as leis de uma simplicidade que desafia a imaginação, e que os fenômenos mais complexos se realizam pelos meios mais elementares; se se considera, enfim, a bondade digna de veneração pela qual essa mesma potência se espalha pelos seres individuais, conforme às leis da insondável sabedoria, com uma generosidade tal, que cuida da criatura mais miserável à mais eminente, estar-seá convencido da necessidade de reconhecer que nenhuma outra consideração natural faz nascer no espírito uma satisfação tão intensa" (Tschirnhaus 18, p. 37-8). 
Se são esses os indícios do lado de Tschirnhaus, quais os que aparecem do lado de Espinosa, assinalando que sabe que as objeções são ou de origem leibniziana ou do próprio Leibniz? Para isso, precisamos considerar alguns fatos anteriores às últimas cartas de Tschirnhaus.

Em outubro de 1671, Leibniz escreve uma carta a Espinosa, respondida por este em novembro do mesmo ano. A carta de Leibniz (mencionada por Espinosa a Schuller, em 1675) é elogiosa, trata de assuntos de óptica e de dióptrica - problemas de refração e de construção de lentes - e oferece a Espinosa um exemplar da Notitia opticae promotae, indagando se o filósofo já conhece a Hypothesis physica, que acaba de publicar, oferecendo-se para mandar-lhe um exemplar, caso ainda não a tenha. A resposta de Espinosa é cordial, também propõe questões de óptica e de dióptrica, a partir do opúsculo recebido, declara não possuir a Hypothesis, indaga se Leibniz já leu o TTP e se dispõe a lhe mandar um exemplar. Pouco antes, em 1669, Espinosa escrevera duas cartas a Jelles tratando justamente das mesmas questões de refração e da construção de lentes para telescópios, de tal maneira que as indagações que, em 1671, dirigirá a Leibniz sobre o que este chama de "lentes pandocais" se inscrevem em perfeita continuidade com o que escrevera a Jelles. A correspondência com Leibniz, entretanto, não prosseguiu. Sabemos, porém, pela carta de Schuller, de 1675, que, entre agosto e setembro de 1675, Tschirnhaus conhece Leibniz em Paris, e também sabemos, pela resposta de novembro desse mesmo ano, o que pensa Espinosa sobre a transmissão do manuscrito da Ética a ele. Em 1676, como vimos, Leibniz passa pela Holanda e, na carta de fevereiro de 1677 , a Galloys, declara haver estado várias vezes com Espinosa.

De que indícios dispomos, então, para considerar que Espinosa reconhece nas questões de Tschirnhaus objeções de Leibniz?

Em primeiro lugar, o laconismo excessivo das respostas. Diferentemente do que sucedera antes, quando oferecia a Tschirnhaus longas explicações e exemplos que o ajudassem a compreender a dificuldade e a resposta, agora Espinosa é de uma brevidade espantosa. Em segundo lugar, afirma a Tschirnhaus que, há muito tempo, já havia considerado os princípios e as regras do movimento propostos por Descartes não só inúteis, mas absurdos 
- afirmação que tem surpreendido os comentadores da obra espinosana, pois parece contradizer outras cartas do filósofo (em que aceita as leis cartesianas, com exceção da sexta), e que, no caso, seria äinda mais surpreendente se considerarmos que Espinosa escreve para alguém que mostrará a carta a Leibniz, o qual, curiosamente, se vangloria de haver explicado os erros da física cartesiana ao filósofo! Ora, se Espinosa faz essa afirmação brutal sobre a física de Descartes e não a acompanha de nenhuma explicação é não só porque essa discussão já foi feita com Leibniz (provavelmente nas visitas de 1676), mas também porque pretende deixar claro em que se distancia de Descartes, e para bom entendedor, meia palavra basta, como ele costuma dizer. Em terceiro, o fato de que, ao final da última carta, sem nenhuma razão aparente, depois de pedir notícias sobre o livro de Huet, Espinosa indaga a Tschirnhaus se este tem notícia de alguma descoberta recente sobre a refração, assunto que fora central na primeira e talvez única troca epistolar com Leibniz, assunto que, na verdade, é inseparável da crítica espinosana à física de Descartes (Chaui 6, Parte III, Cap. 5, 3. "Geometria e imanência").

Todavia, como não se trata de escrever um romance de detetive e como, em outro lugar, já nos ocupamos com as cartas do que chamamos de segunda e terceira etapas da correspondência com Tschirnhaus (id., ibid., p. 695-735), não prosseguiremos examinando essa conjetura, nem as cartas desses dois períodos, mas voltaremos à primeira troca epistolar, quando, em 1674, Tschirnhaus propôs a Espinosa a questão do livre-arbítrio.

\section{III}

Enviada por intermédio de Schuller, a Carta 57 se desdobra em três movimentos articulados internamente: no primeiro, Tschirnhaus apresenta um paradoxo; no segundo, propõe resolvê-lo apelando para a experiência, da qual se poderia extrair uma regra geral; e, no terceiro, entra na questão propriamente dita, a existência ou inexistência do livre-arbítrio. O que arti- 
cula os três movimentos da carta é o pressuposto de que Descartes e Espinosa, aparentemente contraditórios, estão dizendo o mesmo, desde que se possa perceber de onde cada um deles fala ou o ponto a partir do qual suas perspectivas são traçadas.

Qual o paradoxo? Que filósofos, usando o mesmo argumento (eadem ratione), um demonstre algo ser falso e outro, verdadeiro. Esse fato surpreendente pode ser comprovado, por exemplo, quando se compara a afirmação de Descartes, na abertura do Discurso do método, e sua demonstração, nas Meditações, de que a certeza do intelecto é igual para todos, enquanto outros julgam que podem provar algo ser certo porque aceito como indubitável por homens singulares. Em outras palavras, Descartes funda a certeza na universalidade do intelecto, enquanto outros a fundamentam no consenso de indivíduos particulares. E, no entanto, escreve Tschirnhaus, nos dois casos, por certeza os dois partidos entendem o mesmo, isto é, o indubitável.

Como resolver esse paradoxo? Invocando a experiência. Nesse ponto, Tschirnhaus pede a Espinosa que preste cuidadosa atenção no que vai ser dito a seguir. Se de dois homens, um afirma o que outro nega, e ambos estão plenamente cônscios do que estão dizendo, embora pareçam verbalmente contradizer-se, desde que se considerem seus conceitos, ambos dizem a verdade, cada qual em conformidade com seu conceito. Por que invocar essa experiência? Porque ela é útil não só para a vida cotidiana, mas também porque, se considerada, evitaria inúmeras controvérsias e suas conseqüentes disputas, mesmo que essa verdade da concepção (in conceptu) nem sempre seja absolutamente verdadeira, mas é tida por verdadeira segundo o que está pressuposto como verdadeiro pelo intelecto. Essa experiência pode ser tomada como regra universal porque válida para todos os homens, mesmo loucos ou adormecidos, pois tudo aquilo que dizem ver ou ter visto (ainda que não nos apareça da mesma maneira), é absolutamente certo que as coisas se passaram como eles dizem. Em outras palavras, Tschirnhaus julga que a experiência, como regra universal, confirma a teoria cartesiana de que um modo de pensar, enquanto modo de pensar, não possui nenhuma falsidade e que, se conhecermos as condições ou razões de uma afirmação ou 
negação, veremos que, em si mesma, corresponde a uma experiência real, ainda que não corresponda à verdade absoluta das coisas.

Isto posto, e visto que a regra vale em todos casos, trata-se de aplicála a um caso preciso: aqui, o caso do livre-arbítrio. Tschirnhaus pretende mostrar que Descartes e Espinosa, aparentemente contrários, pensam, cada qual à sua maneira, a verdade. Com efeito, prossegue o missivista, tanto aquele que afirma como aquele nega o livre-arbítrio "parecem-me ambos dizer a verdade", dependendo de como cada um deles concebe a liberdade. Chegado a esse ponto, Tschirnhaus apresenta o caso concreto, isto é, a divergência entre Descartes e Espinosa.

"Descartes diz que é livre o que não é coagido por nenhuma causa. Ao contrário, dizeis que é o que não é determinado a alguma coisa por nenhuma causa" (Tschirnhaus, Carta 57; Espinosa 7, G IV, p. 263).

De minha parte, continua ele, concordo convosco de que em todas coisas somos determinados a algo por alguma causa e, portanto, não temos nenhum livre-arbítrio. Porém, concordo também com Descartes que, em certas coisas, não somos de maneira nenhuma coagidos e, assim, temos livre-arbítrio.

Para provar que Descartes e Espinosa têm ambos razão, Tschirnhaus propõe ilustrar sua posição com um exemplo único no qual a presença e a ausência do livre-arbítrio podem ser constatadas. O exemplo é o ato de escrever a carta que está sendo escrita.

A questão deve ser dividida em três partes, diz ele:

$\left.1^{12}\right)$ em sentido absoluto temos algum poder sobre as coisas externas? Resposta: não. De fato, estar aqui neste momento escrevendo esta carta não é algo absolutamente em meu poder, pois ela poderia ter sido escrita antes se eu não tivesse sido impedido de fazê-lo me ausentando ou ficando na companhia de amigos;

$2^{\underline{a}}$ ) em sentido absoluto temos poder sobre os movimentos de nosso corpo, que seguem da determinação de nossa vontade? Resposta: sim, sob 
certas condições, isto é, que estejamos com boa saúde, pois nem sempre posso aplicar-me a escrever ou não;

$\left.3^{2}\right)$ quando estou em posição em que por mim mesmo posso exercer minha razão, posso fazê-lo livremente, isto é, absolutamente? Resposta: sim. "Quem poderia negar-me, senão contradizendo sua própria consciência, que, em meus pensamentos, não posso pensar que quero ou que não quero escrever?" (Tschirnhaus, Carta 57; Espinosa 7, G IV, p. 263).

Assim, não temos poder algum sobre coisas externas, temos um poder relativo sobre os movimentos de nosso corpo determinados pela vontade e temos poder absoluto no que tange ao exercício da razão. Tschirnhaus aceita, portanto, a tripartição cartesiana entre corpo, alma e a "minha natureza", composta dos dois primeiros.

Tschirnhaus volta-se para a segunda parte da questão, isto é, a do poder relativo, pois é nesta que lhe parece situar-se o desacordo entre Descartes e Espinosa. Examinemos a operação de escrever, escreve ele. Visto que as causas externas permitem que ela se realize e que tenho a faculdade tanto de escrever como de não escrever, Tschirnhaus diz concordar com Espinosa de que há causas que determinam essa operação, uma vez que sem elas ele não escreveria. No entanto, prossegue ele, com Descartes e com o testemunho da consciência, afirmo que tais causas não me coagem, pois a despeito delas eu ainda poderia me abster de escrever, o que é impossível negar. E, afinal, se estivéssemos coagidos pelas coisas exteriores, como alcançaríamos o hábito da virtude? Além disso, se assim fosse, toda maldade estaria desculpada. Não acontece também que, determinados a algo pelas coisas externas, no entanto, resistimos de ânimo firme e constante?

Donde a conclusão: aplicada a regra geral, tanto Descartes como Espinosa dizem a verdade. Porém, Espinosa diz uma verdade relativa ao seu próprio conceito de liberdade, enquanto a verdade absoluta encontra-se em Descartes:

"Descartes e vós dizeis a verdade em relação à vossa própria concepção, mas, se se considerar a verdade absoluta, esta pertence à opinião de Descartes" (id., ibid.). 
De fato, explica Tschirnhaus, Espinosa concebe a essência da liberdade como o não sermos determinados por coisa nenhuma e, sob esse aspecto, essa concepção é verdadeira como a de Descartes (certamente Tschirnhaus está pensando na Quarta meditação, quando a vontade escolhe entre o sim e o não segundo o que o entendimento lhe indica, e não nos sentimos determinados à escolha por nenhuma causa externa). Porém, prossegue Tschirnhaus, Espinosa desconsidera o que seja propriamente uma essência, visto que a essência é aquilo sem o que algo não pode sequer ser concebido, e a liberdade pode ser concebida claramente mesmo que sejamos determinạdos em nossas ações por causas exteriores, sem contudo sermos por elas constrangidos, ou seja, sempre há causas que nos incitam a agir de uma certa maneira, mas elas não são causas eficientes completamente. E a liberdade não pode ser de maneira nenhuma concebida se estivermos coagidos.

É possível notar que a argumentação de Tschirnhaus se assemelha, em muitos aspectos, à de um outro correspondente de Espinosa, Blijenbergh ${ }^{(11)}$ e que, como este, também ele mescla idéias cartesianas, estóicas e tomistas, que lhe permitam admitir: 1) a presença de uma causalidade eficiente externa, mas incompleta; 2) a vontade como facultas e portanto como potestas para exercer-se ou não; 3 ) a virtude como hábito adquirido pela potestas de resistir à causalidade das coisas exteriores; e assim por diante. Não menos significativo é o reaparecimento de um tema que ocupa obsessivamente Bljienbergh e que aparece também em cartas de Velthuysen ${ }^{(12)}$ e Oldenburg $^{(13)}$, isto é, a idéia de que a admissão apenas da causalidade eficiente externa desculpa toda maldade e todo vício. Em outras palavras, está implícita a afirmação de que Espinosa é fatalista. Também é sugestivo, como veremos pela resposta de Espinosa, que Tschirnhaus aproxime o conceito cartesiano e o espinosano da liberdade pela ausência de coação e os distinga pela afirmação de Espinosa de que somos determinados a alguma coisa por uma causa. Supõe Tschirnhaus que o fato de termos poder para resistir a uma causa externa confirma, de um lado, a posição de Espinosa - isto é, há sempre causalidade externa -, mas confirma sobretudo a posição de Descartes - a existência da causa externa é irrelevante se ela não tiver o poder para 
nos coagir a uma ação. Por isso a verdade espinosana é relativa e a cartesiana, absoluta.

A resposta de Espinosa é longa, embora passe muito rapidamente por aquilo que Tschirnhaus pretendia que fosse lido com "cuidadosa atenção", isto é, a regra universal trazida pela experiência dos contrários que pensam o mesmo, embora o digam de maneira oposta. Com efeito, Espinosa começa dizendo não haver compreendido o início da carta de Tschirnhaus, mas não explica o que lhe pareceu incompreensível. Logo a seguir, referindo-se ao caso dos que se contradizem e entram em controvérsias, propõe uma correção que anula a regra proposta por Tschirnhaus. De fato, o argumento de Tschirnhaus consistia em afirmar que dois homens, dizendo coisas opostas, poderiam ou estar pensando o mesmo ou cada qual estar pensando algo que corresponderia a uma experiência real e que, portanto, ambos estariam no verdadeiro, mesmo que suas verdades fossem relativas. Espinosa, porém, corrige: Tschirnhaus terá razão se dois homens, enquanto usam as mesmas palavras, pensam coisas diversas ou enquanto pensam o mesmo usam palavras opostas. Qual o sentido dessa correção e que nos envia tanto ao $D e$ emendatione como ao escólio da Proposição 47 da Parte II da Ética - ou ao célebre exemplo do telhado subindo na galinha do vizinho? Espinosa distingue idéia (conceito que a mente forma) e imagem (idéia da afecção corporal), coloca os signos entre as imagens e situa a linguagem na esfera imaginativa. Conseqüentemente, da própria experiência, que se realiza no campo das imagens e dos signos, não virá regra universal nenhuma, pois é ela o lugar em que são gestadas as controvérsias e as disputas verbais. Isso significa, em primeiro lugar, que, diversamente do que supõe Tschirnhaus, Descartes e os que identificam a razão e a certeza com o consenso de indivíduos singulares não estão no mesmo plano nem pensam a mesma coisa com linguagem diversa. Mas significa sobretudo, em segundo lugar, que a brevidade do comentário de Espinosa não nos deve enganar. Ao modificar o texto de Tschirnhaus, Espinosa já o avisa (e nos avisa), implicitamente, que a comparação de sua idéia de liberdade com a de Descartes não poderá reduzi-la a um caso particular e menor da idéia cartesiana. Ele e Descartes não estão pensando o mesmo e por isso não estão dizendo o mesmo. 
"Passo, pois, à definição de liberdade que ele faz minha, mas não sei de onde ele a tirou" (Carta 58; Espinosa 7, G IV, p. 265). Essa passagem é enigmática à luz do que será dito imediatamente a seguir, pois Espinosa oferecerá as definições da coisa livre e da coisa coagida, tais como as encontramos•na Ética, o que nos leva a indagar se Tschirnhaus já teria tido algum acesso ao manuscrito dessa obra, que circulava entre os amigos de Espinosa, quando tudo nos levaria a supor que ainda não e que sua interpretação deveria provir da leitura dos Princípios da filosofia de Descartes, dos Pensamentos metafísicos e, quem sabe, do Breve tratado. Por outro lado e para aumentar nossa dificuldade, no final da carta, Espinosa envia Tschirnhaus aos Pensamentos metafísicos e não às proposições, escólios e prefácios da Ética em que são feitas críticas à vontade livre cartesiana. Além disso, somente pela carta seguinte de Tschirnhaus, depois de haver-se encontrado com Espinosa, percebe-se que, agora, teve acesso aos manuscritos do Tratado da emenda e da Parte I da Ética.

De todo modo, para justificar a estranheza que lhe causou a definição de liberdade que lhe é atribuída por Tschirnhaus, Espinosa oferece a definição da coisa livre e a da coisa coagida:

"Digo ser livre essa coisa que existe e age apenas pela necessidade de sua natureza; coagida, a que é determinada por outro a existir e a operar de uma maneira certa e determinada" (id., ibid.).

Desde já, observa-se que o contraponto é estabelecido não só entre "pela necessidade de sua própria natureza" e ser "determinado por outro", como ainda pela distinção entre o que age pela necessidade de sua própria natureza e o que opera segundo a determinação de um outro.

Mas Espinosa prossegue:

"Deus, por exemplo, existe livre, embora necessariamente, porque existe apenas pela necessidade de sua natureza. Em plena liberdade, Deus também conhece a si mesmo e a todas coisas porque segue apenas de sua natureza que as compreenda. Como vedes, por- 
tanto, não ponho a liberdade numa livre decisão, mas numa livre necessidade" (Carta 58; Espinosa 7, G IV, p. 265).

Dessa maneira, Espinosa desloca inteiramente a definição proposta por Tschirnhaus, uma vez que a distinção entre "livre decisão" e "livre necessidade" pressupõe um completo afastamento da concepção cartesiana da liberdade, de sorte que a redução da definição espinosana a um caso particular e imperfeito da liberdade cartesiana é uma interpretação impossível de ser mantida. De fato, embora Espinosa pareça conservar a idéia clássica e cartesiana, que define a liberdade como espontaneidade de uma natureza na ausência de um constrangimento externo - o que em certa medida explica a interpretação de Tschirnhaus -, acrescenta-lhe, porém, a idéia paradoxal de "livre necessidade", isto é, de uma necessidade que segue espontaneamente da essência da própria coisa, de sorte que a oposição não mais se estabelece entre necessidade e liberdade, mas entre liberdade e coação, o que pressupõe mudança no conceito de necessidade. Dessa mudança dá conta o prosseguimento da carta, quando Espinosa escreve:

"Quanto às coisas criadas, são determinadas a existir e a operar de maneira certa e determinada. Para que entendais, eu vos dou um exemplo simples. Uma pedra que recebe de uma causa externa uma certa quantidade de movimento prosseguirá no movimento até que o impulso externo cesse. Sua permanência no movimento é uma coação externa, não porque seja necessária, mas por definir-se pelo impulso de causas externas. E o que é dito da pedra deve ser dito de toda coisa singular, seja qual for sua complexidade e sua aptidão para uma pluralidade de coisas. Com efeito, cada coisa é necessariamente determinada por alguma causa externa a existir e a operar de maneira certa e determinada" (id., ibid., p. 266).

Se agir é ser livre por necessidade de sua própria natureza, operar é ser determinado pela necessidade de uma causa externa. Mas operar não significa estar coagido. Ou melhor, a coação é uma forma de operar, mas nem 
todo operar é uma coação. A pedra entra em movimento determinada pelo impulso de uma causa externa - seu entrar em movimento é uma operação necessária. Todavia, explica Espinosa, ela prossegue no movimento não porque essa permanência seja necessária, e sim por coação externa, isto é, porque a operação realizada não se define pela natureza da pedra, e sim pelo impulso da causa externa. Isso tem um significado de grande envergadura, pois Espinosa afirma, de uma só vez, que toda coisa singular ou toda coisa criada é determinada por uma causa externa a existir e a operar de maneira certa e determinada, e que uma operação é uma coação quando se define apenas pela natureza da causa externa e não pela natureza da coisa que realiza a operação. Com isso, está preparado o caminho para que se possa pensar o que há de ser a liberdade de coisas determinadas a existir e a operar por uma causa externa. Em outras palavras, Espinosa está afastando a suposição de Tschirnhaus de que ser determinado por uma causa externa significa ipso facto ausência de liberdade.

Nessas primeiras passagens da Carta 58 , podemos, desde logo, perceber que Espinosa retomou a noção clássica da liberdade como espontaneidade de uma natureza na ausência de constrangimento externo, acrescentando-lhe, porém, a idéia paradoxal de necessidade livre ${ }^{(14)}$, isto é, de uma necessidade espontânea que brota da essência do próprio ser, contrapondoa à necessidade de uma causa externa que força alguma coisa a uma existência ou ação que, por si mesma, não possuiria nem realizaria. A diferença, portanto, não se estabelece entre liberdade e necessidade, mas entre liberdade e constrangimento, e o que diferencia o constrangimento da liberdade não é a ausência (nela) ou a presença (nele) da necessidade, mas a interioridade ou exterioridade da causa que incita a existir e agir.

A expressão "livre pela necessidade de sua natureza" reúne termos que a tradição separara e opusera. Com efeito, Espinosa afasta a suposição tradicional de que o necessário é o constrangido, suposição que levava a admitir, em contraponto, que o livre não pode ser necessário. Exclui também um outro aspecto que a tradição julgara decisivo, qual seja, a diferença entre "por natureza" e "por vontade", a primeira expressão significando "por necessidade" e a segunda, "por liberdade" (15). Eis por que a diferença entre 
Deus e a pedra não consiste na presença de uma vontade no primeiro e na ausência dela na segunda: liberdade não é livre decisão de uma vontade, mas a necessidade interna de uma essência de existir e agir segundo a necessidade das determinações que lhe são próprias. Sendo causa de si, Deus age pela livre necessidade de sua essência, enquanto a pedra, em decorrência de sua finitude, de sua natureza extensa e do princípio de inércia que rege todos os corpos, entra em movimento e nele permanece apenas se houver uma causa exterior que a constranja a mover-se.

Que uma ação seja causada, tanto em Deus como em nós, não significa que não seja livre. Essa declaração, que ninguém contestaria, desata, porém, o nó que prendia liberdade verdadeira e liberdade imaginária. Desde Agostinho até Duns Scotus, jamais houve recusa de causa para a liberdade, nem mesmo na tradição ockhamista ou na cartesiana, nas quais a potência absoluta de Deus não é condicionada por nada. A causa da liberdade sempre foi a vontade. Haveria, assim, causas necessárias e causas voluntárias, distinção imprescindível não só para afirmar a potência divina absoluta como ainda para garantir a compatibilidade entre pré-ciência divina e liberdade da ação humana ${ }^{(16)}$. Justamente por haver a tradição elaborado a imagem da causa voluntária é que Espinosa insiste que os homens são cônscios de seus quereres e fazeres, porém ignorantes das causas de seus apetites e desejos, tal ignorância exprimindo-se na noção de causa voluntária. Liberdade, pois, não é ausência de causa, nem ação de uma causa voluntária, mas presença de uma causa necessária interna que exprime a essência do agente. Mas é no momento seguinte que se completa a reviravolta espinosana.

"Concebei agora, se quiserdes, que a pedra, enquanto continua a mover-se, saiba e pense que se esforça tanto quanto pode para continuar a mover-se. Seguramente, essa pedra, visto não ser consciente’ senão de seu esforço, e não ser indiferente, acreditará ser livre e perseverar no movimento apenas porque quer. É esta a tal liberdade humana que todos se jactam de possuir e que consiste apenas em que os homens são cônscios de seus apetites, mas ignorantes das causas que os determinam. É assim que uma criança crê apetecer 
livremente o leite, um rapazinho, se irritado, querer vingar-se, mas fugir, se intimidado. Um ébrio crê dizer por uma livre decisão de sua mente aquilo que, sóbrio, preferiria ter calado. Assim também, um delirante, um tagarela e tantos outros de mesma farinha acreditam agir por um livre decreto da mente e não por impulso. E como esse preconceito é inato em todos os homens, dele não se livram facilmente" (Carta 58; Espinosa 7, G IV, p. 266).

É nesta passagem que Espinosa nos deixa compreender por que introduzira o exemplo da pedra, empregado desde Aristóteles até Gassendi e Hobbes para ilustrar os conceitos de necessidade e liberdade. De fato, ao propor que se imagine a pedra consciente e por isso julgando-se livre porque com vontade de cair, Espinosa retoma o argumento de Agostinho no De libero arbitrio, mas para derrubá-lo.

No Livro III de Do livre arbítrio, Agostinho oferece o caso da pedra para explicar a Evódio a diferença entre "por natureza" e "por vontade". Tomemos o movimento da pedra ao cair, escreve ele, portanto, não um movimento que lhe foi impresso por alguma causa ou força externa, e sim aquele que naturalmente ocorre "quando ela cai na terra por seu próprio peso" (isto é, a gravidade é a causa interna da queda, como se sabe desde Aristóteles). Ao que Evódio retruca: não nego que esse movimento seja natural, porém se o movimento da vontade for desse tipo, não vejo como censurá-la ou reprová-la, pois, "mesmo quando se move para algo mau, é compelida por sua própria natureza" (Agostinho 1, p. 71). Conseqüentemente, prossegue ele, se tal movimento exigir reprovação, não poderá ser natural. Agostinho concordará, porém com uma correção decisiva, isto é, o movimento da pedra é natural e o da vontade, voluntário porque é da natureza da vontade realizá-lo naturalmente. Há, pois, dois tipos de movimentos naturais: o involuntário ou natural propriamente dito e o voluntário porque é da natureza da vontade mover-se. Por onde há de passar a diferença entre o movimento da pedra e o da vontade? 
"Esse movimento da vontade [para a queda] é semelhante ao de uma pedra nisso: esse movimento pertence à vontade como o da queda à pedra. Porém, nisso esses dois movimentos são dessemelhantes: a pedra não tem o poder para interromper seu movimento descendente, mas a alma não é movida para abandonar as coisas mais altas pelas mais baixas a não ser que a vontade assim o queira. Destarte, o movimento da pedra é natural, mas o da alma é voluntário" (De libero arbitrio, III, Agostinho 1, p. 72).

Que diz Espinosa? Se a pedra se tornasse consciente e observasse a si mesma caindo, julgaria que permanece em queda porque assim o quer. $\mathrm{O}$ ponto importante nessa argumentação não é que a pedra, julgando-se livre, julgaria adquirir o poder para interromper a queda ou seu movimento natural - argumento fraco que seria apenas o contraditório do de Agostinho e o deixaria intacto -, e sim que, consciente de seu esforço para perseverar em queda, atribuiria esse esforço ao seu livre querer. Qual a força do argumento espinosano? Mostrar que a imagem da liberdade humana como livre-arbítrio da vontade em nada difere daquela que possuiria uma pedra consciente.

Há uma argúcia sutil na construção desse momento da argumentação: Espinosa fala na consciência da pedra e no impulso dos apetites, isto é, usa para a pedra uma palavra sempre reservada aos humanos (a consciência) e usa para os humanos a palavra que, havia pouco, usara para explicar a permanência da pedra no movimento (o impulso). A pedra acredita saber por que se move: ela se move porque quer; e os humanos acreditam saber por que querem: eles querem porque são capazes de decisões livres. Essa argumentação tem um alvo preciso. De fato, Tschirnhaus invocara o testemunho irrecusável da consciência quando buscara provar que, mesmo sob a ação de causas externas, podemos agir ou não agir porque temos a faculdade e o poder de fazê-lo. Espinosa reduz essa consciência a ilusão, ignorância e preconceito. O movimento voluntário livre, no qual a pedra acreditaria se fosse consciente, em nada difere das crenças da criança, do delirante ou do ébrio, pois é a imagem que todo e qualquer ser consciente possui de seu próprio esforço para existir e operar, desde que ignore as causas que determi- 
nam sua existência e suas operações. Donde a força dos exemplos escolhidos por Espinosa para ilustrar a liberdade imaginária: a pedra pensante, o infante, o delirante e o incontinente.

Em que o argumento de Espinosa se distancia do que vemos usado desde Agostinho até Descartes ou Gassendi? Para todos, o absurdo se encontra na suposição de que a pedra possa pensar que cai por livre-arbítrio. Para Espinosa, que os homens não percebam que, exatamente como a pedra, eles também operam por necessidade de sua natureza.

Todavia, a reviravolta maior ainda está por vir. Espinosa prossegue:

"A experiência nos ensina bastante que nada há de que os humanos sejam menos capazes do que moderar seus apetites e, freqüentemente, às voltas com afetos contrários, vêem o melhor, mas fazem o pior. No entanto, acreditam-se livres porque há certas coisas que neles excitam um leve apetite que pode ser facilmente contrarrestado pela memória de uma outra coisa de que nos lembramos mais freqüentemente" (Carta 58; Espinosa 7, G IV, p. 266).

Essa passagem é extraordinária. Se, ao começar, Espinosa deixara transparecer que somente Deus poderia ser dito livre e se, ao prosseguir, indicara que a imaginação concebe a liberdade a partir dos apetites da criança. faminta e do menino irritado-intimidado, isto é, da visão infantil da independência na qual a liberdade é experimentada como decisão voluntária, e da visão dos incontinentes que se arrependem de seus atos, portanto, da liberdade experimentada como impulso desacorrentado, agora, porém, mostra que possuímos duas crenças exatamente inversas da liberdade: ou cremos que somos livres porque não temos força para dominar um afeto que sabemos ser o pior, ou, inversamente, cremos que somos livres quando nosso apetite é tão fraco que podemos domá-lo com nossas lembranças.

Possuímos duas crenças exatamente invertidas acerca de nossa liberdade: nela cremos ou quando não podemos dominar a força de uma paixão, que nos arrasta para o que sabemos ser o pior, ou, inversamente, quando a paixão é tão fraca que podemos domá-la recordando o que a afasta. Entre o 
agostinismo da primeira crença e a versão vulgar do epicurismo da segunda, a liberdade balouça frágil nas vagas da incerta e caprichosa fortuna.

O percurso está completo. Espinosa considera encerrada a exposição de suas idéias sobre a necessidade livre e a coagida e sobre a liberdade humana imaginária e, "com isso as objeções de vosso amigo estão respondidas". De fato, escreve, se, com Descartes, Tschirnhaus considera livre o homem que não é coagido por nenhuma causa externa, se por coagido ele entender agir contra a vontade, então deve-se conceder que em muitos casos não somos coagidos e que, sob este aspecto, temos livre-arbítrio. Porém, se por coagido Tschirnhaus entender agir necessariamente, mesmo que não seja contra a vontade, é preciso negar, como já foi explicado, que sejamos livres seja no que for. Em outras palavras, se Tschirnhaus mantiver a distinção tradicional entre agir por natureza = agir por necessidade, agir por vontade $=$ agir por liberdade, opondo necessidade e liberdade e identificando necessidade e coação, então, de fato, não somos livres em coisa alguma.

Curiosamente, Espinosa não encerra aí a carta, embora tenha dado por encerradas as respostas às objeções de Tschirnhaus. O prosseguimento indica que passamos agora das respostas às objeções de Tschirnhaus à refutação das teses do missivista, Espinosa tornando-se, agora, o objetor.

Esse momento final da Carta 58 se desdobra em quatro movimentos, nos quais o exemplo de Tschirnhaus, isto é, a ação de escrever uma carta, é reexaminado: no primeiro, Espinosa comenta a idéia de consciência, proposta por Tschirnhaus e vemos aparecer em sua argumentação algumas das idéias desenvolvidas no longo escólio da Proposição 2 da Parte III da Ética; no segundo, retoma a idéia de coação para mostrar por que, em certas circunstâncias, Tschirnhaus não sentiria o impulso para escrever e, em outras, o sentiria; no terceiro, examina as idéias de virtude e maldade e as comenta em termos que lembram passagens de cartas a Blijenbergh; e no último, lança um repto a Tschirnhaus, desafiando-o a resolver racionalmente uma dificuldade deixada por Descartes, qual seja, como conciliar o livre-arbítrio humano e a preordenação divina.

Espinosa recomeça: 
"Vosso amigo objeta que 'podemos exercitar muito livremente nossa razão, isto é, usá-la absolutamente' e persiste nessa asserção com muita confiança, para dizer o mínimo. Pois, diz ele, 'quem poderia dizer, sem ir contra o testemunho de sua própria consciência, que com meus pensamentos posso pensar que quero ou não quero escrever?'. Eu gostaria muito de saber de qual consciência está falando, afora aquela que ilustrei com o exemplo da pedra" (Carta 58; Espinosa 7, G IV, p. 267).

Tenho consciência de que por mim mesmo, pelo poder de meu pensamento, posso querer ou não querer escrever, diz Tschirnhaus. Retruca Espinosa: em que isso difere da pedra pensante? Se esta tivesse consciência, diria que cai porque quer cair. O importante, aqui, é o deslocamento sofrido pela consciência, isto é, ser consciente de algo não significa conhecer isso de que se tem consciência (pois a mera consciência não é conhecimento da causa de alguma coisa) e sobretudo ter consciência não significa dispor de poder absoluto de pensamento. Todavia, tendo indagado o que Tschirnhaus entende por consciência, Espinosa prossegue, explicando o que ele próprio entende por ela:

"De minha parte, para não contradizer minha consciência, isto é, a razão e a experiência, e para não alimentar preconceito e ignorância, nego que, por um absoluto poder do pensamento, posso pensar que quero ou não quero escrever. Mas apelo para a consciência de vosso amigo que, sem dúvida, experimentou em sonhos que ele não tem o poder para pensar que quer ou que não quer escrever, e que quando sonha que quer escrever não tem o poder para não sonhar que quer escrever. Creio que também experimentou que a mente não está sempre igualmente apta a pensar algum objeto, mas, çonforme o corpo (ut in eo hujus) esteja mais apto a excitar a imagem desse ou daquele objeto, a mente está mais apta a contemplar esse ou aquele objeto" (id., ibid.) $)^{(17)}$. 
Espinosa identifica "minha consciência" com a razão e a experiência. Ora, a razão, tanto no Breve tratado como na Emenda do intelecto, é o conhecimento das causas pelos efeitos e, sob esse aspecto, opera exatamente como experiência. Por esse motivo, embora invoque a razão, Espinosa sugere que Tschirnhaus examine a experiência para nela mesma encontrar a refutação de sua tese. Qual a experiência sugerida? Aquela que todo cartesiano é capaz de compreender: a do que se passa no sonho. O interessante, porém, é que o sonho é invocado exatamente por motivos opostos aos de Descartes. Com efeito, que diz Espinosa? Aquele que sonha que pensa que quer escrever não pode, ao mesmo tempo, sonhar que pensa que não quer escrever. A experiência do sonho não é a da liberdade da consciência como poder absoluto de escolha ou de querer/não querer, mas de sua completa determinação. Não é a experiência do desligamento entre o corpo e mente que, liberada das amarras corporais, sonha o que quer, mas, ao contrário, a situação do sonho é exatamente a mesma que a da vigília, isto é, a mente está determinada a pensar em consonância com as imagens excitadas em ou por seu corpo, pois ela não é senão idéia das afecções de seu corpo próprio. Que ensina essa experiência? Que justamente ali, onde se imaginaria o poder absoluto da coisa pensante para querer, ali mesmo está determinada pela imagens corporais a afirmar ou negar algo. Evidentemente, Espinosa não diz que o sonho é uma ação do corpo sobre a mente, e sim que no sonho a mente continua ligada ao seu corpo e às imagens que ele produz ou evoca e que, por conseguinte, ela não exercita um poder absoluto de pensamento, mas depende do que se passa em seu corpo, do qual ela é, por essência, idéia. O sonho é a continuação da vigília em outra maneira, e não uma ruptura da estrutura da relação mente-corpo. Em suma, não há diferença de natureza entre sonho e vigília do ponto de vista da causalidade.

Se assim é, então, Tschirnhaus "sonha de olhos abertos" (para tomarmos uma expressão do escólio da Proposição 2 da Parte III da Ética) quando, desperto, imagina que possui o poder absoluto de escolher escrever ou não escrever. Donde ser preciso concluir que ou a consciência é a razão (que conhece as causas dos efeitos, mesmo que parta dos efeitos) e a experiência (que se realiza no plano dos efeitos), ou é preconceito e ignorância, se con- 
tradisser a razão e a experiência. Voltando contra Tschirnhaus o emprego que este pretendera fazer da experiência, vemos, assim, Espinosa realizar aqui o mesmo procedimento que usará no escólio da Proposição 2 da Parte III da Ética: contrapõe o que a experiência mostra ao que a experiência ensina, contrapõe o que a experiência mostra e o que a razão demonstra, e assinala a harmonia entre o ensinamento da experiência e a demonstração racional.

Todavia, Tschirnhaus não negara que houvesse causas que o levaram a querer escrever ou não escrever, e Espinosa precisa, agora, examinar os argumentos de seu correspondente. De fato, escreve, Tschirnhaus afirma que houve causas que o levaram a querer escrever, mas que elas não o constrangeram a isso. Que quer dizer com isso? Nada mais nada menos que seu ânimo estava num estado em que causas que, noutra ocasião, não o impulsionaram a escrever porque estavam em conflito com outras, por exemplo, um forte afeto, puderam, nesse momento, facilmente dobrá-lo. Em outras palavras,

"causas que não puderam constrangê-lo noutra ocasião, de fato o constrangeram agora, não para escrever contra sua vontade, e sim para necessariamente desejar escrever" (Carta 58; Espinosa 7, G IV, p. 267).

O primeiro aspecto relevante dessas observações de Espinosa encontra-se na mudança de referencial: em lugar de referir-se à mente de Tschirnhaus, refere-se ao seu ânimo. Essa mudança é duplamente necessária para o argumento: em primeiro lugar, estamos passando da suposição de uma vontade livre com poder absoluto de escolha para um desejo determinado por causas afetivas; em segundo, ao passar da consciência como voluntas à cupiditas, estamos na região dos apetites e desejos (como indicam os verbos empregados agora por Espinosa: impulsare, flectere, conflictare) como causas eficientes dos efeitos que aparecem à consciência e dos quais ela pode ser levada a concluir a vontade como causa absoluta. Isso conduz Espinosa a recolocar para o caso da escrita o que já dissera sobre a força ou 
fraqueza dos afetos, acrescentando, agora, que o conflito entre um afeto forte e o desejo de escrever determina não escrever, se tal desejo for mais fraco do que o afeto, e a concluir que a fraqueza temporária de causas que determinariam a escrever pode ser suplantada quando o conflito afetivo desaparece ou quando o afeto forte enfraquece, e que, portanto, ao escrever, alguém não o faz contra a vontade, e sim por necessariamente desejar fazê-lo.

Percebe-se, portanto, que para Espinosa é irrelevante dizer que uma operação foi feita com consciência e foi feita por vontade, pois o essencial é que se faça necessariamente, quer tenhamos ou não consciência de suas causas, quer suponhamos ou não que a realizamos voluntariamente. A questão não se coloca como oposição entre o consciente/voluntário e o necessário, e sim entre a imagem de um poder absoluto de autodeterminação e a experiência da determinação necessária de nossas operações e ações. Em resumo, o equívoco de Tschirnhaus não se encontra na referência à vontade, $\mathrm{e}$ sim a uma vontade livre.

Isso, sem dúvida, conduz ao problema que interessa Tschirnhaus: em que medida a necessidade não contradiz a virtude?

"Quando ele diz que 'se fôssemos constrangidos por causas externas ninguém poderia adquirir o estado de virtude', não sei quem lhe disse que não podemos ter um ânimo firme e constante por necessidade fatal, mas somente por um livre decreto da mente. Quanto à sua observação final, 'isto posto, toda maldade seria excusável', pergunto: de onde segue isso? Os homens maldosos não são menos temíveis nem menos perigosos quando são necessariamente maldosos. A esse respeito, vede, por favor, o Apêndice aos livros I e II dos Princípios de Descartes, Parte II, Cap. 8" (Carta 58; Espinosa 7, G IV, p. 268).

Espinosa começa indagando de onde Tschirnhaus tirou a idéia de que a necessidade impede a firmeza e constância do ânimo, que seriam alcançadas apenas por um livre decreto da mente e quem lhe teria dito que se tudo o que fazemos é necessariamente determinado por causas externas, então, a 
virtude não é alcançada por um esforço da vontade guiada pela razão, os maus estão desculpados e os bons, não recompensados.

Estamos no mesmo universo da correspondência com Blijenbergh (e tantos outros): se formos sempre e necessariamente determinados por causas externas, jamais seremos livres para responder por nossa virtude ou por nosso vício e não seremos justificados nem condenados; a necessidade é incompatível com a moralidade e justificadora do vício e da maldade. Não há liberdade numa filosofia fatalista. A resposta, aqui, é a mesma endereçada a outros correspondentes: a necessidade não exclui a firmeza e constância do ânimo, e os maus são temíveis e perigosos em quaisquer circunstâncias.

Por que Espinosa envia Tschirnhaus ao Capítulo 8 da Parte II dos Pensamentos metafísicos? Essa remissão parece curiosa, pois esperaríamos que enviasse seu correspondente ao Capítulo 12 da segunda parte dos Cogitata, em que trata da mente humana e da vontade, e não ao Capítulo 8, cujo tema é a vontade de Deus. Remetendo Tschirnhaus a esse texto, Espinosa indica que a discussão sobre a liberdade foi deslizando para questões teológicas, e que estas produziram as questões do correspondente. Assim, as indagações de Espinosa - quem lhe disse? de onde tirou isso? de onde segue isso? - têm como resposta: isso vem da tradição religiosa e teológica.

Ora, no Capítulo II, 8, depois de explicar que intelecto, vontade e potência são idênticos em Deus e que tudo o que é, é necessário pela essência (Deus) ou pela causa (coisas singulares finitas), Espinosa propõe objeções de um leitor cristão, ou seja, aquelas mesmas propostas por Tschirnhaus: se tudo é necessário pela vontade e potência de Deus, como explicar que Ele ame ou odeie algumas coisas? Se tudo é necessário pela potência ou vontade de Deus, por que Ele exorta os homens à salvação e pune os ímpios?

À primeira objeção, Espinosa responde com um dos mais caros textos para um cristão reformado, a Epístola aos romanos de Paulo:

"Ele tem compaixão daquele que Ele quer, e endurece aquele que Ele quer. Diz-me, então, por que se queixa ainda? Pois quem é aquele que pode resistir à Sua vontade? Mas, na verdade, ó homem, quem és tu para contestar Deus? Vai acaso a obra dizer ao artífice: 
Chaui, M., discurso (31), 2000: 45-88

por que me fizeste assim? O oleiro não tem sobre a argila o poder para fazer com a mesma massa tanto um vaso para uso nobre, como um outro para uso vil?" (Rom. 9: 19-21).

Quem és tu, ó cristão, para contestares a explicação racional daquilo que confusa e cegamente aceitas pela fé? Não é um artigo de fé que somos como a argila nas mãos do oleiro? Por que a predestinação, ensinada pela fé, seria mais verdadeira do que a necessidade, demonstrada pela razão?

À segunda objeção, Espinosa também responde com as Escrituras. Se se perguntar se Deus poderia salvar os homens sem qualquer exortação, deve-se dizer que sim. Mas, então, por que não o faz?

"Responderei a isso quando me explicares por que Deus não fez o Mar Vermelho transponível sem recorrer a um forte vento do leste e por que não realiza todos os movimentos singulares uns sem os outros e uma infinidade de coisas que produz pela mediação de causas" (CM, II, 8; Espinosa 7, G I, p. 265).

A resposta consiste em afirmar que todos os acontecimentos, mesmo os que são tidos por extraordinários, são naturais e dependem do concurso das causas naturais. Todos os movimentos, sejam ele quais forem, se realizam segundo a necessidade das leis naturais. Por conseguinte, aquele que se salva ou aquele que se perde não fez senão seguir as leis naturais ou as leis de sua própria natureza. Isso, evidentemente, suscita uma nova objeção: por que Deus pune os ímpios, se simplesmente seguem as leis de sua natureza, decretadas por Ele?

"Respondo também que é por decreto divino que são punidos, e se forem punidos aqueles que imaginamos pecar por força de sua liberdade, por que, então, os homens se esforçam para exterminar as serpentes venenosas, se estas pecam por causa de sua natureza própria e não podem fazer doutra maneira?" (id., ibid.). 
Vemos aqui a mesma afirmação feita a Tschirnhaus, qual seja, os maldosos são perigosos e temíveis em quaisquer circunstâncias (afirmação que Espinosa repete na primeira carta enviada a Velthuysen ${ }^{(18)}$. A necessidade natural não exclui a percepção do bom e do mau, simplesmente dá-lhe um sentido novo cujo pressuposto (tema longamente desenvolvido no Apêndice da Parte I da Ética, mas já apresentado no correr dos capítulos da Parte I dos Pensamentos metafísicos) é o afastamento da imagem antropocêntrica da ordem e perfeição da Natureza. Esse afastamento está sutilmente indicado no texto dos Cogitata quando Espinosa identifica "causas naturais", "leis naturais" e "leis de sua própria natureza". De fato, essa identificação derruba a distinção entre ser determinado por causas externas e ser determinado por causas internas - núcleo da objeção de Tschirnhaus ao suposto fatalismo de Espinosa -, na medida em que, externas ou internas, as causas são sempre necessidade natural, e não uma oposição entre necessidade (externa) e liberdade da vontade (interna). Em outras palavras, é este o sentido da identificação em Deus, com que se abre o Capítulo II, 8, do intelecto, da vontade e da potência, poís a vontade sempre fora tida por causa interna que, no dizer de Duns Scotus, "causa contingentemente", e a potência fora concebida como poder para causar externamente efeitos necessários (ou, se se quiser, a primeira era chamada potentia absoluta Dei, e a segunda, potentia ordinata Dei).

A conclusão do Capítulo II, 8 é radical. Visto que a verdade não contradiz a verdade, as Escrituras não podem contradizer a razão natural (observe-se que Espinosa não diz que a razão pode contradizer as Escrituras, e sim o contrário) e, portanto, "não ensina tolices como o vulgar imagina". Mas não só isso.

"Se nelas encontrássemos algo contrário à luz natural, poderíamos refutá-las com a mesma liberdade com que se refuta o Alcorão e o Talmude. Mas longe de nós pensar que se possa encontrar nos Livros Sagrados algo que contrarie a luz natural" (CM, II, 8; Espinosa 7, G I, p. 265). 
A argúcia argumentativa é clara: os cristãos refutam o Alcorão e o Talmude em nome da verdade e da razão, portanto, o mesmo poderia ser feito com as Escrituras, se contradissessem a luz natural. Por conseguinte, se a luz natural demonstra que tudo o que acontece se deve a leis naturais necessárias, o mesmo deverá ser encontrado nas Escrituras, pois, assim não fosse, estas contradiriam a própria razão e seriam refutáveis.

Estamos nas mãos de Deus como a argila nas mãos do oleiro. A verdade não contradiz a verdade. Eis duas teses que nenhum cristão há de recusar. Trata-se, pois, de conhecer suas conseqüências e levá-las racionalmente até o limite. Espinosa devolve, portanto, a Tschirnhaus as objeções, mas dando-lhe uma saída honrosa. Para, logo a seguir, tirar-lhe o tapete sob os pés.

De fato, colocando-se agora na posição de objetor, Espinosa envia a Tschirnhaus uma questão:

"Por fim, gostaria que vosso amigo, que me faz tais objeções, me respondesse como reconcilia a virtude humana, nascida de um livre decreto da mente, com a preordenação de Deus. Se, com Descartes, admite que não sabe conciliá-las, então ele mesmo está traspassado pelo dardo que se esforçava em lançar contra mim. Tentativa frustrada. Pois se examinar com ânimo atento meu parecer, verá que tudo é congruente" (Carta 58; Espinosa 7, G IV, p. 268).

Um filósofo volta a atenção do ânimo para os ensinamentos da razão. Um cristão submete o ânimo aos ensinamentos das Escrituras. Um filósofo cristão sabe que não pode haver contradição entre ambas. Por conseguinte, de duas uma: ou há livre-arbítrio e não há preordenação divina do universo, ou há necessidade universal e não há livre-arbítrio. Mas um filósofo cristão - Descartes, no caso - não pode tirar essa conclusão e precisa afirmar que ignora como se conciliam livre-arbítrio e preordenação. Ora, a escolha da Epístola aos romanos e o exemplo da abertura do Mar Vermelho por causas naturais indicam por que a posição de Espinosa é, como ele mesmo afirma, congruente: o livre-arbítrio da vontade é uma das "tolices que o vulgar imagina". 


\section{IV}

Ao iniciar, distinguimos três fases na correspondência entre Tschirnhaus e Espinosa. Todavia, não há que supor que o problema da primeira troca epistolar tenha desaparecido. É interessante observar que ele retorna com nova roupagem e pode, de alguma maneira, explicar por que a presença de Leibniz acabasse sendo tão importante para Tschirnhaus (como vimos na descrição das perfeições de Deus, com que se abre a Medicina mentis).

De fato, praticamente em todas as cartas seguintes, quando já conversou com Espinosa, já leu os manuscritos do De emendatione e do De Deo, Tschirnhaus indaga obsessivamente como deduzir a priori da extensão infinita todos os corpos singulares e suas variações. Essa interrogação tem como pressuposto o problema de difícil (ou quase impossível) solução para Tschirnhaus, qual seja, a recusa espinosana da teologia da Criação do mundo e a demonstração de que todos os seres (no caso, todos os corpos) seguem da necessidade e perfeição da essência/potência de Deus. É verdade que Tschirnhaus formula suas questões ora do ponto de vista da matemática, ora do ponto de vista da física, ora do ponto de vista da metafísica, porém, subjaz a esses pontos de vista a perspectiva teológica cristã.

Em outras palavras, se não é mais a definição do livre-arbítrio nem a conciliação deste com a preordenação divina, ou com a necessidade natural, que aparecem nas cartas seguintes, é porque nelas a idéia de dedução geométrica a priori do universo a partir da necessidade da essência/potência da extensão (ou de um atributo da substância absolutamente infinita) atinge o cerne da questão da liberdade, pois se refere à liberdade da vontade divina no momento da Criação. E que, desde o início, Espinosa sabia disso, o envio de Tschirnhaus ao Capítulo II, 8 dos Pensamentos metafísicos é a nossa melhor prova. 
Abstract: Spinoza's correspondence with Tschirnhaus, which began shortly before the publication of the Theologico-political treatise and ended a few months before the philosopher's death, is of marked importance not only because it contains Spinoza's last writings, but above all because it includes discussion of some of the most important themes in his philosophy. In this article we will mention the implicit presence of Leibniz in Tschirnhaus last letters, but we will only treat the first exchange of letters, whose subject is the disagreement between Tschirnhaus and Spinoza regarding freedom.

Key-words: freedom - liberty - will - free-will - contingency - necessity - fatalism

\section{Notas}

(1) Veja-se, a respeito desse tema, os artigos de F. Akkerman (Akkerman $2 e$ 3). Está em curso uma nova edição crítica com tradução francesa pelo GRS.

(2) Como é o caso da Carta 12A de Espinosa a Meijer, de 26 de julho de 1663, sobre a publicação dos Renati des Cartes Principiorum Philosophiae e os Cogitata Metaphysica, publicada pela primeira vez por A.K. Offenberg, sob os cuidados da Biblioteca da Universidade de Amsterdã, republicada, em 1978, com uma tradução inglesa em Speculum Spinozanum 1677-1977 e com uma tradução francesa na Revue Philosophique, nº 3, 1977 (Espinosa 8).

(3) Na época, está em curso a guerra entre a Holanda e a França, donde a preocupação de Espinosa com a presença de um diplomata alemão na corte de Luís XIV. Veja-se a esse respeito Friedmann 9 e Nadler 15.

(4) "Espinosa morreu este inverno. Passando pela Holanda eu o vi e com ele conversei várias vezes e longamente. Ele tem uma estranha metafísica, cheia de paradoxos. Entre outras coisas, crê que o mundo e Deus não são senão uma mesma coisa em substância, que Deus é a substância de todas as coisas e que as criaturas não são senão modos ou acidentes. Mas observei-lhe que algumas das demonstrações que me mostrou não são exatas. 
Não é tão fácil como se pensa dar verdadeiras demonstrações em metafísica. No entanto, há algumas e muito belas. Não se pode tê-las antes de haver estabelecido boas definições, que são raras", Carta de Leibniz a Galloys, de fevereiro de 1677 (Leibniz 11, Vol. I, p. 179). Numa carta também a Galloys, publicada por Foucher de Careil, lemos: "Passei algumas horas após o jantar com Espinosa, que me disse que, no dia do massacre dos senhores De Witt, teve o impulso de sair à noite e pregar em alguma parede próxima do local um cartaz com os dizeres ultimi barbarorum. Mas seu hospedeiro fechou as portas da casa para impedi-lo de sair, pois ele se exporia a ser destroçado. Espinosa não percebia muito bem os defeitos das regras do movimento do senhor Descartes e ficou surpreso quando the mostrei que violavam a igualdade da causa e do efeito".

(5) Conforme a publicação da correspondência entre Schuller e Leibniz, feita por L. Stein (Leibniz und Spinoza, 1890) e comentada por Friedmann, que observa que certamente Leibniz possuía pelo menos o manuscrito da Parte I, porque, numa carta de abril de 1677, Tschirnhaus lhe escreve dizendo-lhe que entenderá a definição espinosana de Deus, desde que "legisse scriptum ejus hac de re elaborantum" (Friedmann 9, p. 294). Confirma isso a publicação das cartas de Schuller a Leibniz nos Sämtliche Schriften und Briefe, Vol. III, Secção 6, Berlim, Akademie-Verlag, 1980, p. 275-83.

(6) Georg Hermann Schuller, originário da mesma região que Tschirnhaus, foi seu colega no curso de medicina da Universidade de Leiden, e, certamente, foram os contatos com outros estudantes dessa universidade, amigos de Espinosa, que o fizeram se aproximar do filósofo (a quem Tschirnhaus talvez tenha sido apresentado pelo Barão de Nuland, militar de carreira, curioso de filosofia e polidor de lentes, conhecido de Huygens e de Jan de Witt, e comandante do regimento em que Tschirnhaus se alistou, como voluntário da República holandesa, durante a guerra com a França, em 1672; cf. Vermij 16). Possivelmente, Schuller e Tschirnhaus freqüentaram juntos a casa de Espinosa e seu círculo de amigos. Conforme escreve Tschirnhaus a Leibniz, em abril de 1678, foi Schuller quem lhe deu uma cópia manuscrita do De Emendatione $e$, mais tarde, cópias de todas as obras do filósofo. Várias das cartas de Schuller a Espinosa são apenas as de um intermediário que oferece a exposição de questões e dúvidas de Tschirnhaus ao 
filósofo, bem como relatos das atividades de Tschirnhaus quando este viaja pela Europa. A historiografia sobre Schuller é pouco abonadora de sua conduta (Klever 10). Além de problemas financeiros e dívidas, envolvendo outros amigos do círculo dos estudantes de Leiden, querelas e disputas variadas com eles, Schuller teria prometido a Leibniz enviar-lhe o manuscrito da Ética, mesmo sem o consentimento de Espinosa e, segundo algumas versões, não só teria revirado os papéis de Espinosa enquanto este agonizava, como teria brigado por eles durante o funeral. Também segundo algumas versões, Schuller teria induzido o editor Rieuwertz a oferecer o manuscrito a Leibniz ou teria induzido Leibniz a oferecer-se ao editor para a compra. De acordo com G. Friedmann, a correspondência entre Schuller e Leibniz, em 1677-8, resume as tratativas de ambos quanto à obra de Espinosa: 1) em fevereiro de 1677, após anunciar-lhe a morte de Espinosa, Schuller propõe a Leibniz a compra do ms. da Ética, por 150 florins; 2) em março de 1677, Schuller retira a proposta, porque os amigos decidiram publicar os Opera Posthuma; 3) entre outubro e novembro de 1677, Leibniz manifesta pressa em receber os ms. dos Opera Posthuma e ms. que não tenham sido incluídos na publicação; 4) em dezembro de 1677, Schuller comunica que a obra está impressa, mas só será distribuída a partir de janeiro de 1678; 5) em janeiro de 1678, Schuller envia um exemplar da obra e se desculpa por haver permitido que uma carta de Leibniz figure na publicação; 6) Leibniz se zanga ao saber da inclusão da carta, e Schuller, em março de 1678, pede novamente desculpas, critica a irresponsabilidade do editor e acalma Leibniz, dizendo-lhe que não corre qualquer perigo, pois sua carta contém apenas questões matemáticas (Friedmann 9, p. 295).

(7) Entre Tschirnhaus e Espinosa foram trocadas 11 cartas. Uma vez que muitos aspectos da correspondência com Tschirnhaus decorrem de cartas entre Schuller e Espinosa, vamos inclui-las neste conjunto; por razões que aparecerão em nossa exposição, também vamos incluir como parte dessa correspondência a breve troca epistolar entre Espinosa e Leibniz. Neste caso, o conjunto é formado pelas seguintes cartas: Carta 45, outubro de 1671, de Leibniz a Espinosa; Carta 46, outubro de 1671, de Espinosa a Leibniz; Carta 57, outubro de 1674, de Schuller/Tschirnhaus a Espinosa; Carta 58, outubro de 1674, de Espinosa a Schuller/Tschirnhaus; Carta 59, junho de 1675, de Tschirnhaus a Espinosa; Carta 60, junho de 1675, de Es- 
pinosa a Tschirnhaus; Carta 63, julho de 1675, de Schuller a Espinosa; Carta 64, julho de 1675, de Espinosa a Schuller; Carta 65, agosto de 1675, de Tschirnhaus a Espinosa; Carta 66, agosto de 1675, de Espinosa a Tschirnhaus; Carta 70, novembro de 1675, de Schuller a Espinosa; Carta 72, novembro de 1675, de Espinosa a Schuller; Carta 80, maio de 1676, de Tschirnhaus a Espinosa; Carta 81, maio de 1676, de Espinosa a Tschirnhaus; Carta 82, julho de 1676, de Tschirnhaus a Espinosa; Carta 83, julho de 1676, de Espinosa a Tschirnhaus.

(8) A Carta 49, de dezembro de 1673, é de Espinosa a Graevius, solicitando a este o envio de uma cópia da carta sobre a morte de Descartes, que Simon de Vries deseja ler; cf. Espinosa 7, G IV, p. 238.

(9) Cf. K.O. Meinsma 12, p. 391. De fato, em fevereiro de 1671, numa carta a Jelles, Espinosa diz que Graevius, numa recente visita, avisou-o de que alguém pretendia traduzir o TTP para o holandês e Espinosa pede ao amigo que se informe sobre isso e impeça a tradução, pois se ela acontecer, coisa que os bons amigos (entre os quais Graevius) não desejam, o livro será proibido pelas autoridades calvinistas. Ora, em abril de 1672, Graevius escreverá uma carta a Leibniz, comunicando-lhe a aparição de um livro pestilentissimus, cujo título ele fornece erradamente (chamando-o de Discursus Theologicus-Politicus), cujo autor diz ele ser "um certo judeu, chamado Espinosa, há muito expulso da sinagoga par suas opiniões monstruosas" e sugere que "Velthusium nostrum" poderá fazer excelente refutação. Por seu turno, na resposta, Leibniz declara que leu o livro, lamenta que "um homem tão culto pudesse cair tanto" e espera que alguém, erudito nas coisas cristãs, o refute; cf. Carta de Graevius a Leibniz, abril de 1671, e Carta de Leibniz a Graevius, maio de 1671 (Leibniz 11, p. 141-8). Portanto, ao escrever a Graevius, em 1673, Espinosa ignora o que este tramava às suas costas, mas certamente, na altura de 1674-75, já não ignora o que se passa, ainda que Tschirnhaus não saiba das relações entre Graevius e Leibniz.

(10) Essas proposições da Ética possuem os seguintes enunciados: I, P16: "Da necessidade da natureza divina devem seguir infinitas coisas em infinitos modos (isto é, tudo o que pode cair sob um intelecto infinito)"; I, P17: "Deus age somente segundo as leis de sua natureza sem ser coagido por 
ninguém"; I, P28: "Qualquer coisa singular, ou seja, finita e que tem existência determinada não pode existir nem ser determinada a operar e a existir senão por uma outra causa que também é finita e tem existência determinada; e por sua vez, esta causa também não pode existir nem ser determinada a operar se não for determinada a existir e a operar por uma outra que também é finita e tem existência determinada, e assim ao infinito (in infinitum)" (Espinosa 7, G II, 60-1, 69).

(11) Cf. o conjunto de cartas de 1665 (Cartas 19 a 27).

(12) Cf. Carta 42, janeiro de 1671, de Velthuysen a Ostens.

(13) Cf. Cartas 61, junho de 1675, 62, julho de 1675, 71, novembro de 1675, 74, dezembro de 1675, 79, fevereiro de 1676, de Oldenburg a Espinosa. Perdeu-se uma carta que Oldenburg diz haver enviado antes de junho de 1675 , com considerações ácidas sobre o TTP e que, pela Carta 61, teriam sido amenizadas numa nova leitura do Tratado, possivelmente sob a influência de Tschirnhaus, o qual, no entanto, não é mencionado por Oldenburg.

(14) Essa expressão (embora não literalmente, mas com esse sentido) aparece em Plotino no Tratado 39, Enéada VI, 8. Todavia, ali o sentido de uma liberdade necessária ou de uma necessidade livre articula-se à afirmação plotiniana de que o Primeiro-Uno está além do ser e da essência e que tudo quanto digamos dele é incapaz de exprimi-lo (Plotino 16 e 17). Ao contrário, Espinosa emprega o conceito de necessidade livre ou de liberdade necessária para referir-se a uma propriedade intrínseca do ser absolutamente infinito cuja essência podemos conhecer perfeitamente. Cf. M. Chaui 6, Parte III, Cap. 6, 1, b. Causa sui: o princípio da philosophia, p. 759-92.

(15) Traços da distinção tradicional entre livre e natural parecem presentes na obra anterior à Ética. No Capítulo 3 da Parte I do Breve tratado, ao enumerar os oito aspectos da causalidade eficiente divina, o filósofo escreve: "Investiguemos, pois, como e de que maneira Deus é causa [...]. 3) Deus é uma causa livre e não uma causa natural" (I, 3 (I)). E, no Capítulo 4: "A verdadeira liberdade consiste unicamente em que a causa primeira, sem ser constrangida nem necessitada por nenhuma outra coisa, somente por sua perfeição produz toda perfeição [...]; livre não no sentido de que possa fazer ou não fazer alguma coisa, mas no sentido de que não depende de nada 
outro, de sorte que o que Deus faz, Ele o faz e executa na qualidade de causa supremamente livre" $(I, 4(5,8))$. Observe-se, porém, que ao opor causa livre e causa natural: 1) Espinosa não opõe, como se poderia supor, voluntário e necessário, mas, pelo contrário, recusa que livre signifique poder ou não fazer alguma coisa e, portanto, que livre signifique voluntário; 2) a diferença é estabelecida entre o que é determinado por si mesmo (livre) e o que é determinado ou constrangido por outro (natural). E é neste sentido que, tanto no $\mathrm{BT}$ como na Ética, o filósofo repetirá que a vontade não pode ser causa livre porque é determinada por uma outra causa. Assim, mesmo que o vocábulo "vontade" seja mantido por Espinosa, seu sentido foi subvertido, deixando de significar o livre poder para fazer ou não fazer algo (ou para querer ou não querer algo) para significar ser determinado a fazer ou a querer algo.

(16) É significativa, por exemplo, a solução agostiniana: nossa vontade é uma causa criada por Deus para agir livremente, e por isso, ainda que a ciência de Deus saiba qual será nossa ação, tal ciência não é causa de nosso agir porque a causa dele é nossa vontade.

(17) Podemos supor que essa primeira correspondência com Tschirnhaus tenha levado Espinosa a redigir o longo escólio da Proposição 2 da Parte III da Ética (G II, p. 141-4), pois ali vemos desenvolvido o argumento sumariamente exposto aqui.

(18) De fato, ao criticar o TTP, Velthuysen afirmara que o fatalismo de Espinosa não dava lugar para recompensas e punições e que os justos e pecadores estavam postos na mesma condição. $O$ argumento de Velthuysen baseava-se no fato de Espinosa recusar a idéia de mandamentos divinos como leis decretadas por um soberano e um juiz. À crítica, Espinosa responde: "A necessidade inevitável das coisas não suprime nem as leis divinas nem as humanas. Com efeito, quer os ensinamentos morais recebam ou não do próprio Deus a forma de lei, são divinos e salutares; quer recebamos o bem que segue da virtude e do amor de Deus como se o recebêssemos de um juiz ou como emanando da necessidade da natureza divina, não é mais ou menos desejável; nem os males que seguem de más obras hão de ser menos temidos por seguirem necessariamente delas", Carta 43, Espinosa 7, G IV, p. 222. 


\section{Referências Bibliográficas}

1. AGOSTINHO, S. Augustine. On free choice of the will. Trad. por T. Williams. Indianapolis, Hackett, 1993.

2. AKKERMAN, F. "L'édition Gebhardt de l'Éthique de Spinoza et ses sources”. In: Raison Presente, nº 43, 1977.

3. __ "Vers une meilleure édition de la correspondence de Spinoza?" In: Revue Internationale de Philosophie, $\mathrm{n}^{0}$ 119-120, 1977.

4. Studies in the Posthumous Works of Spinoza. On style, earliest translation and reception, earliest and modern edition of some texts. Groningen, Rijksuniversiteit te Groningen, Krisp Repro Meppel, 1980.

5. AKKERMAN, F. \& HUBBELING, H.G. "The preface to Spinoza's Posthumous Works". In: Lias, n² 6, 1977.

6. CHAUI, M. A nervura do real. Imanência e liberdade em Espinosa. Vol. 1: Imanência. São Paulo, Companhia das Letras, 1999, 2 ts.

7. ESPINOSA, B. Spinoza Opera. Im Auftrag der Heidelberger Akademie der Wissenschaften herausgegeben von Carl Gebhardt. Heidelberg, C. Winter, 1925; 2 . Auflage 1972, 4 vols. (abreviado como $G$ ).

8. _L_ "Letter from Spinoza to Lodewijk Meijer, 26 July 1663". Ed. por A.K. Offenberg. In: HESSING, S. (ed.). Speculum Spinozanum 16771977. Londres, Routledge \& Kegan Paul, 1978; trad. francesa na Revue Philosophique, n 3, 1977.

9. FRIEDMANN, G. Leibniz et Spinoza. Paris, Gallimard, 1962.

10. KLEVER, W. "La clé d’un nom: Petrus Van Gent”. In: Cahiers Spinoza, no 6, 1991. 
11. LEIBNIZ, G.W. Die mathematischen Schriften. Herausgegeben von C.J. Gerhardt. Berlim, Weidmann, 1849-63, 7 vols. Reimpressão: Hildesheim, G. Olms, 1978.

12. Allgemeiner Politischer und Historischer Briefwechel. Preussischen Akademie der Wissenschaften. Vol. I. Darmstadt, Otto Reichl Verlag, 1923.

13. Euvres choisies. Ed. por L. Prenant. Paris, Aubier-Montaigne, 1972.

14. MEINSMA, K.O. Spinoza en zijn kring. Historisch-kritsche studien over Hollandsche vrijgeesten (s'-Gravenhage, 1896). Reimpressão: Utrecht, M. Nijhoff, 1980 / Spinoza et son cercle. Étude historique et critique sur les hétérodoxes hollandais. Trad. do holandês por S. Roosenburg, apêndices latinos e alemães trad. por J.P. Osier, intr. e notas por H. Méchoulan e P.-F. Moreau. Paris, J. Vrin, 1983.

15. NADLER, S. Spinoza. A life. Cambridge, Cambridge University Press, 1999.

16. PLOTINO. Plotin. Ennéade VI. Traité 38. Texto estabel., apres., trad. e anot. por É. Bréhier. Paris, Belles Lettres, 1932.

17. Plotinus. The Enneads. Trad. por S. MacKenna; com introd. e notas por J. Dillon. Harmondsworth, Penguin, 1991.

18. TSCHIRNHAUS, E.W. von. Médecine de l'esprit ou préceptes généraux de l'art de découvrir. Introd., trad., notas e apêndices por J.P. Wurz. Paris, Ophrys, 1980.

19. VERMIJ, R. "Le spinozisme en Hollande: le cercle de Tschirnhaus". In: Cahiers Spinoza, n² 6, 1991

20. WURTZ, J.-P. “Um disciple 'hérétique' de Spinoza: Ehrenfried Walther Von Tschirnhaus”. In: Cahiers Spinoza, n 6, 1991. 